DOI: https://doi.org/10.32839/2304-5809/2020-12-88-38

УДК 338.28

Ясіновська І.Ф., Іщенко В.А., Жовтяк К.В.

Львівський національний університет імені Івана Франка

\title{
ДЕРЖАВНО-ПРИВАТНЕ ПАРТНЕРСТВО: ТЕОРЕТИЧНИЙ АСПЕКТ ТА ОСОБЛИВОСТІ РЕАЛІЗАЦІЇ В УКРАЇНІ
}

\begin{abstract}
Анотація. У статті досліджено суть та особливості механізму державно-приватного партнерства (ДПП). Висвітлено ознаки та форми здійснення державно-приватного партнерства, передбачені законодавством України. Систематизовано основні переваги ДПП як для держави, так і для приватного бізнесу. Проаналізовано динаміку кількості проєктів, реалізованих в рамках державно-приватного партнерства в Україні. Досліджено територіальний розподіл проєктів державно-приватного партнерства, а також визначено пріоритетні сфрери національної економіки, в яких застосовуеться даний механізм. Виокремлено актуальні проблеми розвитку державно-приватного партнерства в нашій державі. Проаналізовано приклади зарубіжного досвіду успішної реалізації проектів ДПП та можливості їх імплементації за сучасних умов соціально-економічного розвитку України.
\end{abstract}

Ключові слова: державно-приватне партнерство, інноваційно-інвестиційний розвиток, проєктне фінансування, договір концесіі, приватний сектор.

Yasinovska Iryna, Ishchenko Veronika, Zhovtiak Kateryna

Ivan Franko National University of Lviv

\section{PUBLIC-PRIVATE PARTNERSHIP: THEORETICAL ASPECT AND FEATURES OF REALIZATION IN UKRAINE}

Summary. The essence and features of the mechanism of public-private partnership (PPP) were investigated in the article. The definition of "public-private partnership" that are given in foreign and domestic research, was analyzed. It was found that in modern market economy cooperation between the state and business is a tool that can attract significant investment in priority areas of the national economy. The main condition for the demand to implementation of mechanism of public-private partnership in our country is the fast growth of needs to public services and the limited resources and possibilities of the state. The characteristics and forms of public-private partnership provided by the legislation of Ukraine were described. The main advantages of public-private partnership for both the state and private business were systematized. The dynamic of using projects implemented on conditions of public-private partnership in Ukraine were analyzed. Despite public-private partnership is only developing in Ukraine, the number of PPP projects increase every year. The territorial structure of public-private partnership projects is investigated. PPP projects are implemented in 16 of the 24 regions of Ukraine. Moreover, in some regions several projects are implemented in different industries. The priority areas of the national economy where this mechanism is applied were identified, such as: water collection and depuration, natural gas transportation, infrastructure, electricity generation, tourism, health care, etc. The actual problems of public-private partnership development in our state were highlighted. Examples of foreign experience of successful implementation of PPP projects and possibilities of their implementation for modern conditions of economic development in Ukraine were analyzed. It is concluded that cooperation between the state and business structures is extremely important for Ukraine. That's why the private sector is increasingly consolidating its position as an equal partner in solving important community development challenges. That's why the private sector has finally become an equal partner in solving important community development challenges.

Keywords: public-private partnership, innovation and investment development, project financing, concession agreement, private sector.

$\Pi$ остановка проблеми. У мінливих умовах ринкової економіки важливо забезпечити стабільні темпи економічного зростання та загалом покращення потенціалу країни задля забезпечення її конкурентоспроможності на світовій арені. Одним із шляхів реалізації національних інтересів країни є формування сприятливого інноваційно-інвестиційного середовища, яке слугує підгрунтям для трансформаційних процесів в економіці. Серед інвестиційних інструментів яскраво вирізняеться державно-приватне партнерство (ДПП), яке дозволяе втілити низку важливих та масштабних соціально-економічних проєктів. Адже, зазвичай, такі проєкти характеризуються постійними обмеженнями в бюджетній та фрінансовій сфрерах. Тому державно-приватне партнерство є тим самим меха- нізмом, який дозволяє активізувати реалізацію таких проєктів на засадах рівноправного та взаємовигідного співробітництва держави та приватного бізнесу. За таких умов актуальним $є$ пошук ефрективних фрорм взаємодії держави та бізнесу, дослідження їх правовідносин та втілення зарубіжного досвіду фоунціонування державно-приватного партнерства у нашій країні.

Аналіз останніх досліджень і публікацій. Не зважаючи на те, що державно-приватне партнерство в Україні знаходиться поки що на початковій стадії свого розвитку і не $є$ досить поширеною практикою, певні методологічні питання сутності та особливостей даного механізму знайшли своє відображення в наукових працях вітчизняних вчених, серед яких В. Андрійчук, А. Мокій, В. Геєць, І. Павленко, С. Свірко, О. Соб- 
кевич. Окрім того, аспекти діяльності суб'єктів господарювання у контексті державно-приватного партнерства входять до кола наукових інтересів багатьох закордонних науковців.

Виділення не вирішених раніше частин загальної проблеми. Незважаючи на усі теоретичні та практичні здобутки в дослідженні механізму державно-приватного партнерства, потрібно зауважити, що в контексті сучасних економічних змін дане питання все ще залишаеться недостатньо дослідженим і потребує подальшого комплексного вивчення та систематизації.

Мета статті. Метою даного дослідження $є$ аналіз та систематизація теоретичних та практичних аспектів, а також подальших векторів розвитку державно-приватного партнерства в Україні. Відповідно до поставленої мети, завданнями статті було визначено: з'ясування ключових ознак та форм державно-приватного партнерства; виокремлення актуальних проблем розвитку та висвітлення особливостей реалізації проєктів за допомогою державно-приватного партнерства Україні; дослідження зарубіжного досвіду застосування механізму державно-приватного партнерства та його імплементація для нашої держави.

Виклад основного матеріалу. Як показуе світова практика, за сучасних ринкових умов держава та приватний бізнес мають безліч спільних соціально-економічних інтересів, а отже не можуть працювати та розвиватися незалежно один від одного. Одним із едективних інструментів такого співробітництва, який активно використовується закордоном, а останнім часом розвивається і в Україні, є державно-приватне партнерство (ДПП). Вирішальною умовою необхідності впровадження механізму державно-приватного партнерства в нашій країні є постійне зростання потреб у суспільних послугах та одночасна обмеженість ресурсних можливостей держави для їх задоволення. Держава защікавлена в залученні приватних інвестиційних ресурсів для спільної реалізаціі проєктів в пріоритетних секторах національної економіки. Саме тому сьогодні приватний сектор все більше закріплюе свої позиції рівноправного партнера у вирішенні важливих завдань розвитку громад. Тому співпраця держави і бізнесу є вкрай важливою для України [6, с. 161].

У зарубіжних та вітчизняних дослідженнях представлені різноманітні визначення дефіні- ції «державно-приватного партнерства», проте усі вони характеризують однакові його особливості. Наведемо одне з таких визначень, яке на нашу думку найбільш широко розкриває сутність ДПП: «це засноване на договорі довгострокове співробітництво між державними органами та органами місцевого самоврядування 3 одного боку, а також приватними компаніями з іншого, що спрямоване на фрінансування, проєктування, впровадження та управління публічними об'єктами і послугами, які традищійно забезпечуються державою» [3, с. 5]. Загалом сутність державно-приватного партнерства полягає в системі відносин між державними та приватними партнерами, за яких відбувається об'єднання їх ресурсів з відповідним розподілом ризиків, повноважень та винагород щодо реалізації певних інвестиційних проєктів. Досвід як економічно розвинутих країн, так і країн, що розвиваються, переконливо демонструє, що проєкти державноприватного партнерства дозволяють залучати приватний капітал в інфраструктурні та соціальні проєкти та забезпечити стрімке економічне зростання навіть за незначних фінансових вкладень держави.

В Україні даний інструмент взаємодії держави та приватного сектору закріплений на законодавчому рівні Законом України «Про державно-приватне партнерство» від 01.07.2010 року № 2404-VI із змінами i доповненнями. Даним законом визначено базові ознаки державно-приватного партнерства (рис. 1). Проаналізувавши їх, можемо зробити висновки, що механізм ДПП передбачає насамперед пріоритетність інтересів держави. Так, саме органи влади виступають головним ініціатором будь-якого інвестиційного проєкту і визначають напрямки та правила співпраці з бізнес-структурами. Довготривалість співпраці державних та приватних партнерів створює значні переваги. Адже це дає можливість через механізм ДПП залучати значні обсяги фінансових ресурсів на тривалий час, без відчуження об’єків державної або комунальної власності, і таким чином реалізовувати масштабні проєкти. Окрім того, державно-приватне партнерство завжди передбачає чіткий розподіл ризиків, при чому вони передаються тій стороні, яка зможе забезпечити більш ефективне управління ними. Також державно-приватне партнерство має базуватися на принципі прозорос-

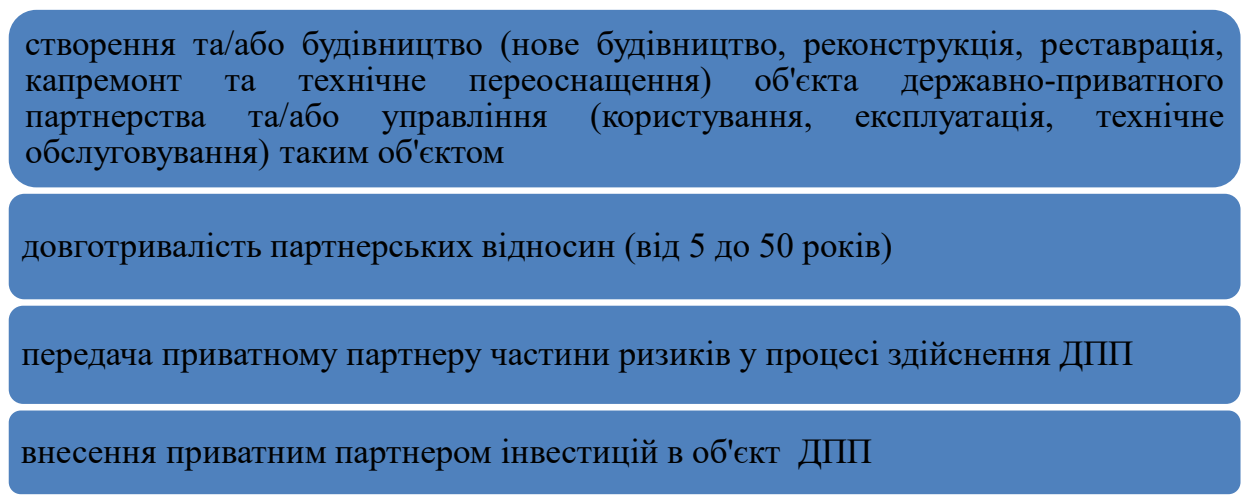

Рис. 1. Основні ознаки державно-приватного партнерства в Україні 
ті, населення обов'язково повинно мати доступ до інформації відносно діяльності приватних та державних партнерів [2].

Різноманітність комбінацій можливої співпраці між державним та приватним секторами залежить від особливостей сощіально-економічного розвитку країни, регіону, галузей, напрямків діяльності, суб'єктів та об'єктів співпраці, характеристик проєктів та інших чинників. I насправді, в світовій практиці ідеальної форми державноприватного партнерства не існує. Кожна країна використовуе свої інструменти розвитку державно-приватного партнерства. У статті 5 ЗУ «Про державно-приватне партнерство» закріплені основні форми співпраці держави та приватного партнера (рис. 2). На нашу думку, чинне законодавство не достатньо чітко визначає форми ДПП. I серед них може мати місце будь-яка інша фpopма взаємодії, що закріплена на основі договору (інші договори) і відповідає ознакам державноприватного партнерства та здійснюеться на засадах проєктного фрінансування. Тому доповнити перелік також можемо досить поширеними в Україні формами ДПП, як наприклад, договір оренди, лізинг, інвестищійний договір, договір про розподіл продукції тощо. Так як в Україні державно-приватне партнерство перебуває на активній стадії свого становлення, то, відповідно, можливих реалізованих кейсів співробітництва держави та бізнесу відносно небагато [6].

Варто зазначити, що серед форм ДПП значно переважають договори концесії, за якими об'єкти державної власності передаються у тимчасове користування приватним підприемствам. Причому, необхідною умовою для здійснення такої передачі є обов'язкове інвестування приватними інвесторами в такі об'єкти [1].

Державно-приватне партнерство як фрорма організації проєктного фінансування вирізняється 3-поміж інших форм фрінансування та передбачає безліч переваг як для держави, так і для приватного бізнесу. Такі основні переваги систематизовано на рис. 3.

\section{Для держави}

- Скорочення витрат на надання послуг

- Активізація інвестиційної діяльності

- Ефективне управління майном

- Економія фінансових ресурсів держави

- Використання досвіду приватних компаній

- Оптимізація розподілу ризиків

- Розвиток форм проєктного фінансування

- Стимулювання підприємницького мислення

- Рівноправний діалог між владою та бізнесом

- Збереження та створення робочих місць

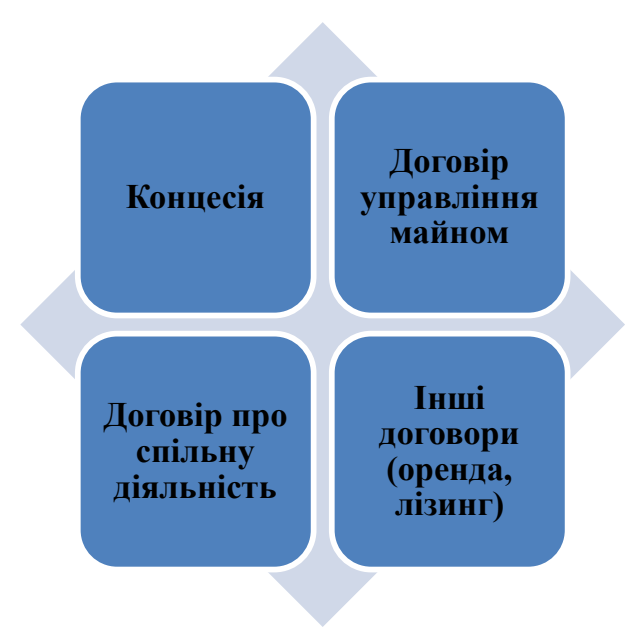

Рис. 2. Форми здійснення

державно-приватного партнерства в Україні

Джерело: сформовано авторами за даними [8]

На сьогодні, ринок проєктів ДПП в Україні перебуває на стадії становлення. Разом з тим, стала динаміка зростання кількості проєктів, які реалізуються в рамках ДПП, відповідно до статистичних даних Міністерства розвитку економіки, торгівлі та сільського господарства України, ще раз доводить підвищення зацікавленості як з боку держави, так і з боку приватного сектору економіки у реалізащії проєктів саме у такий спосіб (рис. 4).

Як бачимо 3 даних рис. 4, кількість проєктів, які втілюються в життя через ДПП за 2012-2019 роки має тенденщію до збільшення, тобто щороку зростала, і лише у 2019 році зменшилась на 2 одиниці. Таке зменшення є несуттевим і не впливає на загальну динаміку реалізащії проєктів ДПП. Зазвичай, воно пов'язане із станом виконання угод ДПП, адже в силу певних обставин, успішній реалізащії проєкту може завадити розірвання угоди внаслідок невиконання однією із сторін обумовлених в ній зобов'язань один перед одним.

\section{Для приватного сектору}

• Залучення бюджетних коштів до проєкту

- Доступ до раніше закритих сфер економіки (ЖКГ, інфраструктура тощо)

- Розширення можливостей отримання пільгових кредитів під державні гарантії від міжнародних та вітчизняних фінансових установ

- Поліпшення роботи з державними дозвільними органами

- Підвищення статусу проєкту через участь у ньому державного партнера

- Позитивний імідж у суспільстві

- Оптимізація розподілів ризику проєкту

Рис. 3. Переваги ДПП для держави та бізнесу 


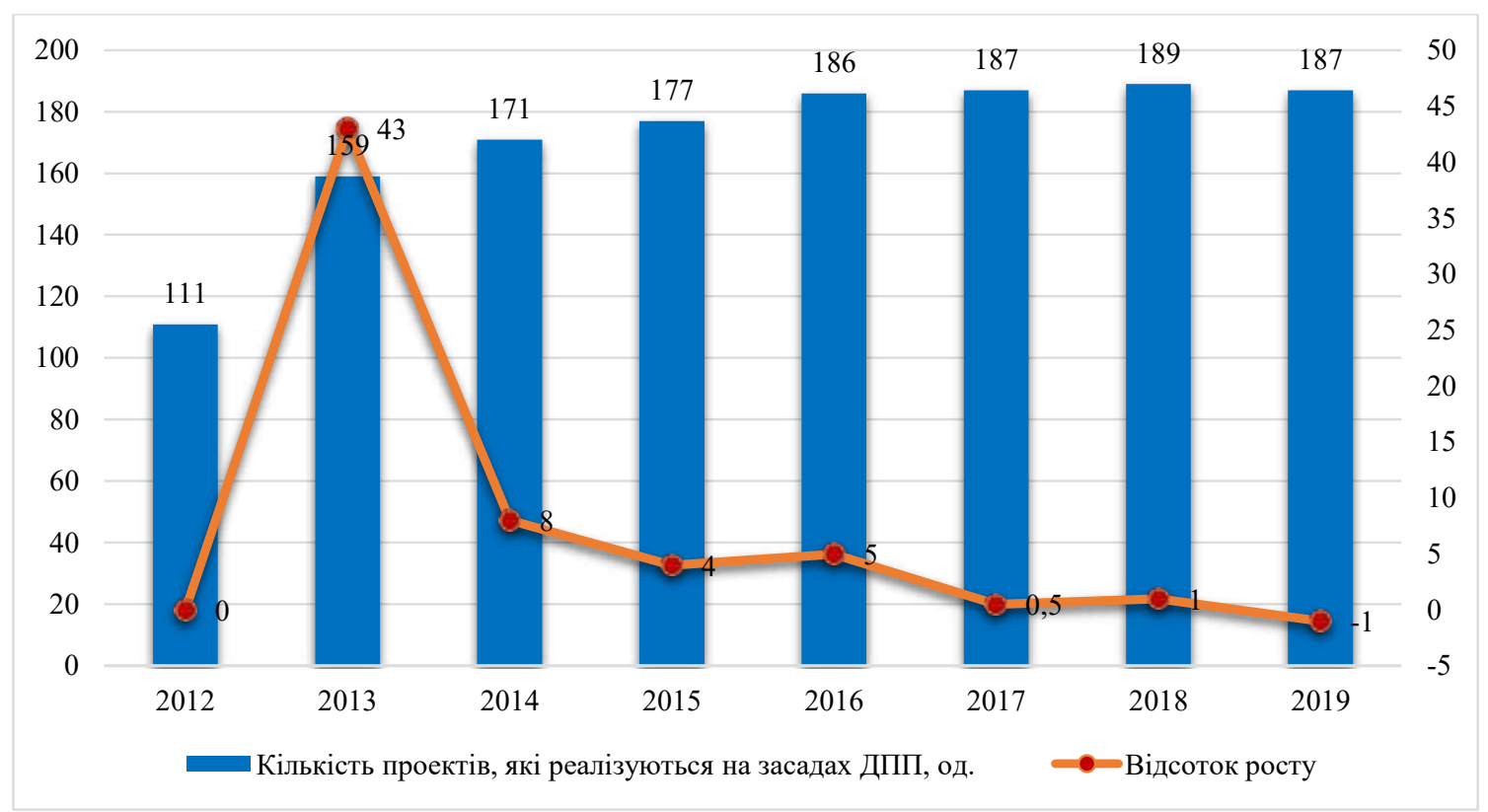

Рис. 4. Динаміка кількісного та відсоткового росту проектів, які реалізуються на засадах ДПП в 2012-2019 роках

Джерело: сббормовано авторами за даними [3; 9]

Відтак, пропонуємо розглянути як здійснюється розподіл угод державно-приватного партнерства за статусом їх виконання (рис. 5). Загалом протягом 2019 року було укладено 187 угод на засадах ДПП (рис. 4). Проте з них були реалізовані лише 52 договори. Натомість, 135 договорів мали статус тих, що не виконуються, зокрема 18 таких угод було розірвано, щодо 4 завершився термін діï, а 113 угод є такими, які мають статус «не виконано». Відповідно, незважаючи на чітку тенденцію до збільшення кількості угод за участі ДПП, частка угод, які реалізовані є майже втричі меншою за ті, що мають статус «тих, що виконуються». Це свідчить, про те, що стан ДПП в Україні знаходиться на перехідній стадії від етапу становлення до етапу розвитку. Однак, задля успішної реалізації таких проєктів необхідна не лише кількісна, але й якісна складова механізму ДПП.

При здійсненні аналізу стану ДПП в Україні важливо також враховувати географрічний чинник. Зокрема, на рис. 6 відображено реалізовані проєкти у розрізі окремих областей станом на кінець 2019 року.

Територіальний розподіл проєктів ДПП свідчить про те, що найбільша кількість проєктів реалізуеться на території Миколаївської області (11 або 21\% від загальної кількості реалізованих проєктів). Разом 3 тим, у Київській та Одеській областях реалізуеться по 6 проєктів ДПП, що становить по $12 \%$ від загальної кількості реалізованих проєктів. Порівняно значна частина проєктів ДПП реалізуеться у Львівській та Донецькій (по 5 або по 10\%), Закарпатській та Запорізькій (по 4 проєкти, частка кожного 8\%) областях. В усіх інших областях реалізується невелика кількість (1-2) проєктів на засадах ДПП.

Як правило, на умовах державно-приватного партнерства реалізовуються проєкти у тих сдрерах національної економіки, які передбачають надання суспільно значущих послуг, за виключенням тих видів діяльності, які відповідно до законодавства можуть здійснюватися виключно державни-

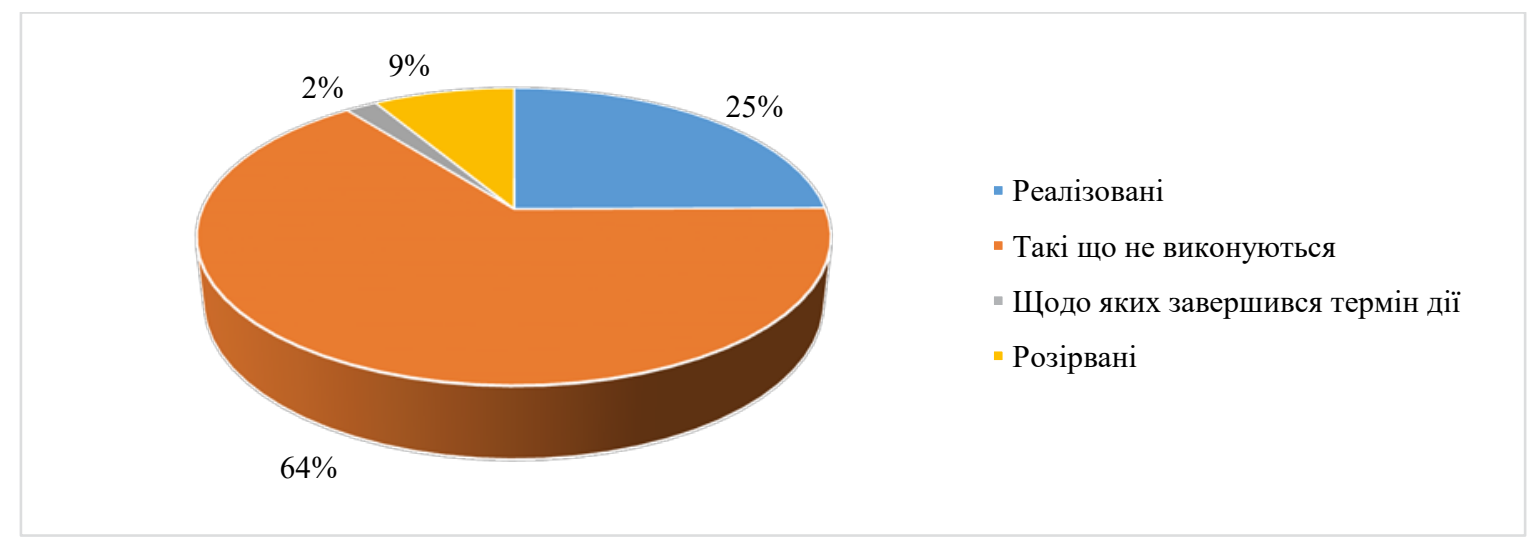

Рис. 5. Розподіл угод державно-приватного партнерства в Україні за станом виконання на кінець 2019 року

Джерело: сфборловано авторами за даними [9] 


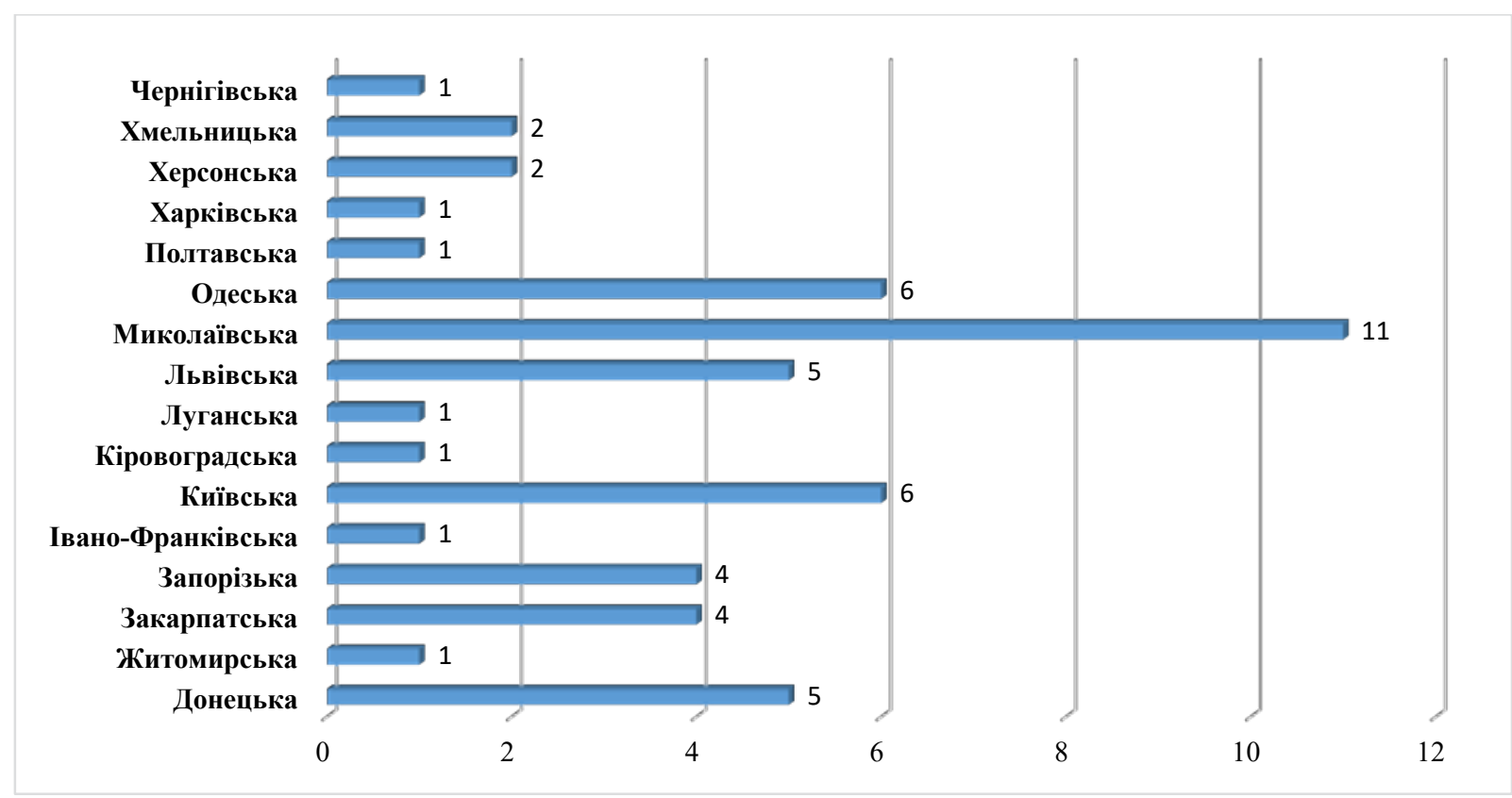

Рис. 6. Розподіл угод державно-приватного партнерства в Україні за областями станом на кінець 2019 року, од.

Джерело: собормовано авторами за даними [9]

ми установами та підприемства. На підставі даних рис. 7, можемо зробити висновок, що в Україні найбільша кількість проєктів ДПП реалізуеться у cфpepi збору та очищення води - загалом 21 проєкт за підсумками 2019 року. Також пріоритетними сфрерами, де застосовуеться механізм державно-приватного партнерства, $є$ транспортування природного газу та інфраструктура -8 та 7 діючих проєктів відповідно. Окрім того, перспектива державно-приватного партнерства $є$ у сферах охорони здоров'я, туризму та виробництва електроенергії. На жаль, зовсім мало проєктів ДПП реалізуеться в галузі обробки відходів та розвідки корисних копалин. Вважаємо, що в Україні потрібно розвивати співпрацю держави з бізнесом у таких досить актуальних і стратегічно важливих напрямах.

Результати аналізу стану державно-приватного партнерства в Україні свідчать про необ- хідність підвищення ефективності партнерських відносин між державою та приватним сектором, що дозволить реалізувати більшу частку проєктів. На нашу думку, цілком доцільним і актуальним $є$ вивчення світової практики ДПП. Тому, пропонуемо розглянути основні аспекти реалізації проєктів ДПП на прикладі світового досвіду, який доводить, що за умови грунтовного підходу до втілення проєктів ДПП, можна досягнути високих показників.

Приклад Великобританії в контексті державно-приватного партнерства дуже показовий. Саме ця країна є одним із світових лідерів в реалізації проєктів ДПП. На сьогоднішній день тільки в сфрері охорони здоров'я тут реалізовують понад 130 проєктів ДПП, включаючи проєкт будівництва лікарні St. Bartholomew вартістю 1,1 млрд фрунтів стерлінгів [5, с. 12].

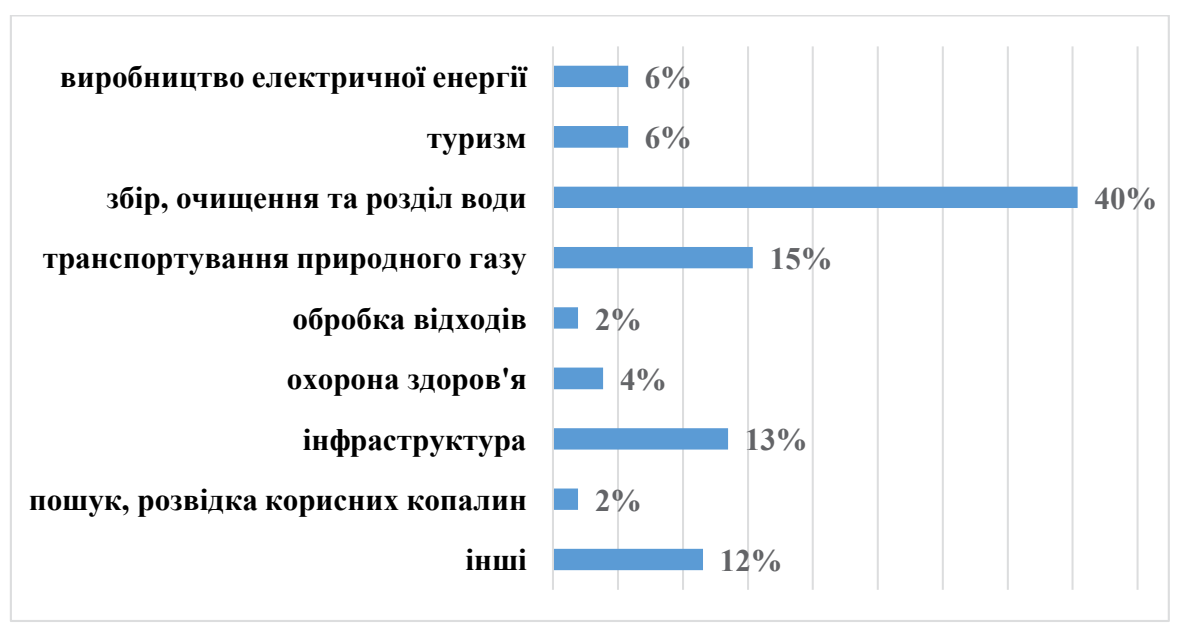

Рис. 7. Структура проектів державно-приватного партнерства в Україні за сферами діяльності станом на кінець 2019 р. 
Також, говорячи про приклади вдалої реалізації проєктів державно-приватного партнерства, зокрема у сфрері транспортної інфрраструктури, варто відзначити позитивний досвід Мадагаскару та Республіки Бенін. Наприклад, концесія порту «Тоамасіна» (Мадагаскар) в межах державно-приватного партнерства, за свідченнями експертів, дозволила підвищити рівень потужності обробки вантажів з 60 до 2500 тонн на добу, тоді як завантаження та розвантаження контейнерів збільшилося з менше ніж 10 одинищь до більше ніж 30 одиниць за годину на одне судно. Час, необхідний для обробки та відправки контейнерів, скоротився з кількох днів до кількох годин, а кількість днів для митного оформлення за 3 роки скоротилася з 5 до 2,6. Як результат, збільшення трафріку в порту призвело до більшої інтеграції зі світовими ринками, а також до збільшення інвестицій у промисловість у зв'язку з підвищенням защікавленості потенщійних інвесторів у реалізації проєктів в регіоні [4].

У 2009 р. була підписана угода щодо концесії порту «Котону» (республіка Бенін), висока вартість послуг, низька ефективність та погане матеріально-технічне оснащення якого не давали можливості стати ключовим торговельним маршрутом. У процесі реалізації проєкту державно-приватного партнерства було створено 450 нових робочих місць, збільшено пропускну спроможність порту, трафрік контейнерів зріс вдвічі протягом перших 2-х років реалізаціі проєкту, зменшено вартість транспортних витрат, що розширило експортний коридор для внутрішніх районів країни та дало поштовх для розвитку суміжних галузей економіки (зокрема, ринку сільського господарства та рибної промисловості). За попередніми оцінками, загальна dpicкальна вигода від реалізації проєкту становить 200300 млн. доларів США [4].

Підвищення рівня привабливості інвестиційного клімату, що сприятиме нарощенню обсягів залучення іноземного капіталу; зменшення вартості користування довгостроковими інвестиційними кредитами; вдосконалення нормативно-правової бази в напрямку покращення захисту інтересів інвесторів; розширення та вдосконалення роботи мережі спеціальних фрінансових інститутів (інвестиційних фондів та банків, лізингових, фракторингових, форорейтингових компаній тощо) сприятимуть зменшенню інвестиційних ризиків та активізації розвитку державно-приватного партнерства та проектного фрінансування загалом в Україні. У свою чергу, створення сприятливих умов розвитку проектного фінансування сприятиме додатковому залученню іноземних інвестицій в національну економіку та її структурній перебудові [10, с. 167].

Висновки і пропозиції. Державно-приватне партнерство як одна 3 фором проектного фрінансування успішно зарекомендувало себе у світовій практиці. За сучасних умов ринкової економіки співпраця держави та бізнесу $є$ інструментом, який дозволяе залучити значні інвестицї в пріоритетні сорери національної економіки. Унаслідок цього, приватний сектор може розраховувати на державну підтримку, отримавши доступ до окремих ресурсів або інфрраструктури, а держава - вдало реалізовувати насправді важливі та нагальні проєкти, притому зекономивши свої обмежені фрінансові ресурси і зменшивши ризики.

В Україні державно-приватне партнерство перебуває на етапі становлення. Офіщійне регулювання відносин між державою та бізнесом веде свій відлік порівняно недавно, а саме від прийняття Закону України «Про державно-приватне партнерство» у 2010 році. Втім, не зважаючи на це, в нашій країні є масштабний потенціал для реалізації проєктів ДПП. Про це свідчить територіальний розподіл проєктів ДПП, за яким такі проєкти реалізуються у 16 з 24 областей України. Причому, у деяких областях реалізуеться відразу кілька різнопланових проєктів. Також, про значний потенціал механізму ДПП говорить диференщіащія напрямків і сорер діяльності проєктів. Зокрема, протягом 2019 року найбільше проєктів було реалізовано у таких сфрерах як збір та очищення води, транспортування природного газу та інфраструктура.

Протягом аналізованого періоду спостерігається загальна тенденщія до збільшення кількості проєктів у рамках ДПП. Проте не всі проєкти вдаеться втілити в життя. Зокрема, за 2019 рік лише 52 проєкти із 187 вдалося реалізувати. Тому можна 3 впевненістю стверджувати, що ефективність партнерських відносин між державою і приватним сектором економіки залежить не лише від кількості укладених угод, але й від низки інших фракторів. Перш за все необхідно вдосконалити нормативно-правову базу механізму ДПП, яка б чітко окреслювала права й обов'язки сторін. Також, важливим каталізатором розвитку ДПП може стати вивчення іноземного досвіду та його імплементація в українських реаліях. Це, безумовно, допоможе активізувати не лише ринок державно-приватного партнерства, але й загалом інвестиційно-інноваційну діяльність в країні.

\section{Список літератури:}

1. Акімова О. Новий закон про концесію: чого очікувати інвесторам. Main business partner. URL: https://mbusinesspartner.com.ua/kontsesiya (дата звернення: 27.11.2020).

2. Глянцев В. Чому державно-приватне партнерство привабливе для розвитку інвестпотенціалу бізнесу. Delo.ua : веб-сайт. URL: https://delo.ua/opinions/chomu-derzhavno-privatne-partnerstvo-privablive-363180/ (дата звернення: 27.11.2020).

3. ДПП як механізм реалізації нової регіональної політики: можливості застосування та практичні аспекти підготовки і впровадження інвестиційних проектів. Група радників з впровадження державної регіональної політики в Україні Програми «U-LEAD з Свропою». 2017. URL: http://rdpa.regionet.org.ua/images/129/ PPP_report_U-LEAD_30_10_2017.pdf (дата звернення: 30.11.2020).

4. Зуева Ю. Закордонні кейси 3 ДПП: порівняльний аналіз. Юридична газета опline. 2020. № 1(707). URL: $\quad$ https://yur-gazeta.com/publications/practice/derzhavnoprivatne-partnerstvo/zakordonni-keysi-z-dppporivnyalniy-analiz.html (дата звернення: 02.12.2020).

5. Кнір М.О. Державно-приватне партнерство: світовий досвід і досвід України. Наукові записки Національного університету "Острозька акаделія". Серія "Еконоліка» : науковий журнал. Острог : Вид-во НаУОА, вересень 2018. № 10(38). С. 10-14 
6. Крутова А.С., Тарасова Т.О., Кащена Н.Б. Проекти державно-приватного партнерства: реалізащія та аналіз ефективності. Еконолічний простір. 2019. № 141. С. 158-171. URL: http://srd.pgasa.dp.ua:8080/xmlui/ handle/123456789/1555 (дата звернення: 30.11.2020).

7. Левковська Л.В., Мандзик В.М., Чередніченко Ю.Г. Джерела та напрями фрінансового забезпечення водогосподарського комплексу України. 2015. URL: http://nbuv.gov.ua/j-pdf/piprp_2015_3\%281\%29_29.pdf (дата звернення: 02.12.2020).

8. Про державно-приватне партнерство : Закон України від 01.01.2010 № 2424-VI (зі змінами та доповненнями). URL: https://zakon.rada.gov.ua/laws/show/2404-17\#Text (дата звернення: 27.11.2020).

9. Стан здійснення ДПП в Україні. Міністерство розвитку еконоліки, торгівлі та сільського господарства України. URL: https://www.me.gov.ua/Documents/Detail?lang=uk-UA\&id=9fc90c5e-2f7b-44b2-8bf1-1ffb7ee1be26\&title=StanZdiisnenniaDppVUkraini (дата звернення: 27.11.2020).

10. Yasinovska I., Sheremeta O. Management of investment risks in the system of project financing. Інноваційна еконоліка : Науково-виробничий журнал. Тернопіль, 2019. № 5-6 [80]. С. 164-168.

\section{References:}

1. Akimova O. Novyi zakon pro kontseciiu: chogo ochikuvaty investoram [New concession law: what to expect from investors]. Main business partner. Available at: https://mbusinesspartner.com.ua/kontsesiya (accessed 27 November 2020).

2. Hliantsev V. Chomy derzhavno-pryvatne partnerstvo pryvablyve dlia rozvytku investpotentsialu biznesu [Why public-private partnership is attractive for the development of business investment potential]. Delo.ua. Available at: https://delo.ua/opinions/chomu-derzhavno-privatne-partnerstvo-privablive-363180/ (accessed 27 November 2020).

3. Grupa radnykiv z vprovadzhennia derzhavnoi regionalnoi polityky v Ukraini Programy «U-LEAD» z Yevropoiu (2017) DPP yak mexanizm realizatsii novoi regionalnoi polityky: mozhlyvosti zastosuvannya ta praktychni aspekty pidgotovky i vprovadzhennia investycijnykh proektiv. PPP as a mechanism for implementing a new regional policy: application possibilities and practical aspects of preparation and implementation of investment projects. Available at: http://rdpa.regionet.org.ua/images/129/PPP_report_U-LEAD_30_10_2017.pdf (accessed 30 November 2020).

4. Zuieva Yu. (2020) Zakordonni keisy z DPP: porivnialnyi analiz [Foreign cases with PPP: a comparative analysis]. Yurydychna gazeta online (electronic journal), no. 1(707). Available at: https://yur-gazeta.com/publications/practice/ derzhavnoprivatne-partnerstvo/zakordonni-keysi-z-dpp-porivnyalniy-analiz.html (accessed 02 December 2020).

5. Knir M.O. (2018) Derzhavno-pryvatne partnerstvo: svitovyi dosvid i dosvid Ukrainy [Public-private partnership: world experience and experience of Ukraine]. Scientific notes of the National University "Ostroh Academy". Series "Economics": a scientific journal, no. 10(38), pp. 10-14.

6. Krutova A.S., Tarasova T.O., Kashchena N.B. (2019) Proekty derzhavno-pryvatnogo partnerstva: realizatsiia ta analiz efektyvnosti [Projects of state-private partnership: realization and analysis of efficiency]. Economic space, no. 141, pp. 158-171. Available at: http://srd.pgasa.dp.ua:8080/xmlui/handle/123456789/1555 (accessed 30 November 2020).

7. Levkovska L.V., Mandzyk V.M., Cherednichenko Yu.G. (2015) Dzherela ta napriamy finansovogo zabezpechennia vodogospodarskogo kompleksu Ukrainy [Sources and directions of financial support of the water management complex of Ukraine]. Available at: http://nbuv.gov.ua/j-pdf/piprp_2015_3\%281\%29_29.pdf (accessed 02 December 2020).

8. Law of Ukraine on public-private partnership № 2424-VI. (2010, January, 01). Vidomosti Verkhovnoyi Rady Ukrainy. Available at: https://zakon.rada.gov.ua/laws/show/2404-17\#Text (accessed 27 November 2020).

9. Stan zdiisnennia DPP v Ukraini [The state of PPP implementation in Ukraine]. Ministerstvo rozvutky ekonomiky, torgivli ta silskogo gospodarstva. Available at: https://www.me.gov.ua/Documents/Detail?lang=uk-UA\&id=9fc90 c5e-2f7b-44b2-8bf1-1ffb7ee1be26\&title=StanZdiisnenniaDppVUkraini (accessed 27 November 2020).

10. Yasinovska I., Sheremeta O. (2019) Management of investment risks in the system of project financing. Інноваційна еконоліка: Науково-виробничий журнал. Тернопіль, nо. 5-6 [80], pp. 164-168. 